\title{
CLIMATE CHANGE IN LITERATURE AND LITERARY CRITICISM
}

Adam Trexler and Adeline Johns-Putra

\section{Abstract:}

This article provides an overview of climate change in literature, focusing on the representation of climate change in Anglophone fiction. It then evaluates the way in which these fictional representations are critiqued in literary studies, and considers the extent to which the methods and tools that are currently employed are adequate to this new critical task. We explore how the complexity of climate change as both scientific and cultural phenomenon demands a corresponding degree of complexity in fictional representation. For example, when authors represent climate change as a global, networked, and controversial phenomenon, they move beyond simply employing the environment as a setting and begin to explore its impact on plot and character, producing unconventional narrative trajectories and innovations in characterization. Then, such creative complexity asks of literary scholars a reassessment of methods and approaches. For one thing, it may require a shift in emphasis from literary fiction to genre fiction. It also particularly demands that environmental criticism, or ecocriticism, moves beyond its long-standing interest in concepts of 'nature' and 'place', to embrace a new understanding of the local in relation to the global. We suggest, too, that there are synergies to be forged between these revisionary moves in ecocriticism and developments in literary critical theory and historicism, as these critical modes begin to deal with climate change and reimagine themselves in turn.

Climate change now occupies a primary position not just on political and scientific agendas but in the wider cultural imagination. Just five years ago, Robert Macfarlane bemoaned the dearth of creative response to climate change, asking, 'Where are the novels, the plays, the 
poems, the songs, the libretti, of this massive contemporary anxiety?'. ${ }^{1}$ Now, it seems apparent that climate change and its effects are being articulated in a range of literary and critical works.

This article provides a brief overview of representations of climate change in fiction, before looking at the ways in which literary scholarship deals with such representations. Literary studies has a number of approaches that are relevant to climate change fiction, and these are evaluated for their usefulness. Finally, it proposes avenues for future research on climate change and fiction.

Specifically, we hope that, in sketching out the way in which climate change has been dealt with in fiction, this article conveys some idea of the unique challenge it presents to authors. Needless to say, climate change is as culturally as it is scientifically complex. It possesses an immensity of scale both spatially (as a global event) and temporally (as an unprecedented crisis in human history). It is marked by a necessary degree of scientific imprecision about the extent and speed of climate change, met by public confusion, controversy and scepticism, which is sometimes quick to construe scientific imprecision as uncertainty and even conspiracy. Its solutions require network and negotiation, not magic bullets nor heroes. The sheer complexity of such a phenomenon, we suggest, provokes and inspires authors to invent and innovate, in order that they can adequately imagine, depict, and convey it.

Correspondingly, then, the cultural phenomenon of climate change (that is, these inventive and innovative depictions of climate change) requires from literary scholarship something of a re-adjustment of the approaches and methods it has hitherto applied to literature and the environment. As we suggest below, climate change asks of literary scholars nothing more or less than a re-evaluation of themselves - a consideration of the discipline's bias toward the 'literary’ (itself a troublesome term) and a willingness amongst 
environmental literary critics, in particular, to move beyond comfort zones. In particular, we outline how familiar notions such as setting, place and nature-mainstays of environmental literary criticism—are being revisited and renovated in response to climate change and climate change fiction.

Beforehand, we would like to note that we deal here with climate change in fiction, as, although we anticipate that there will be more research on poetry and plays about climate change, thus far there does not seem to have been much work in these areas. Moreover, whilst the problem of climate change is beginning to be addressed in other forms of prose, such as travel writing, nature writing, and life writing, we focus on fiction, as its imaginative demands—including plot and character-are very different from those of non-fiction. This is not to say that non-fictional forms do not possess their own challenges, but that these challenges relate to the scientific discourse of climate change in a way that is distinct from fictional discourse and are, regrettably, beyond the scope of this article.

In addition, we have focused on Anglophone fiction, not just because we have found little evidence of climate change fiction in languages other than English but also because the field of literary studies tends to be language-sensitive, with university departments, and hence research, usually developing along linguistic lines (as our discussion of single-text and single-author studies might suggest). Nonetheless, we acknowledge that a comparative literary approach is a promising avenue for future research into climate change and literature.

\section{CLIMATE CHANGE FICTION}

First, we survey fiction that represents the issue of anthropogenic climate change as it came to be understood in scientific exchange and the broader public consciousness from the 1970s onwards. The past two decades have seen an increasing amount of fiction dealing with this issue, and a particular explosion in the numbers of such novels in the past ten years. 
Notwithstanding this, the immediate phenomenon of climate change and its representation in fiction possesses a pre-history of literary portrayals of worldwide environmental change, with which we will deal briefly. However, we discount more general representations of global climate in the history of Western literature, recognising that a survey of such would be virtually unmanageable, necessarily stretching back to ancient narratives, especially religious and apocalyptic ones, such as the Epic of Gilgamesh,$^{2}$ the story of the flood in the Old Testament Book of Genesis, and the Last Judgement of the New Testament Book of Revelations. $^{3}$

For this pre-history of fictional representations of climate change, it is helpful to turn first to science fiction. Science fiction specialises in constructions of other-worlds, or what Suvin has called 'novums' (34), ${ }^{4}$ and such worlds are often depicted as being caused by or subjected to extreme environmental change. We can further categorise these other-worlds as extra-terrestrial and/or futuristic, their strangeness a factor of planetary or temporal shift, or both.

The depiction of ecological change in extra-terrestrial terms is often allied to the theme of terraforming, that is, intentionally making planets habitable by changing their climate, a term and idea introduced by the writer Jack Williamson in a series of short stories in 1942 and $1943 .{ }^{5}$ We find terraformed settings in science fiction classics such as Arthur C. Clarke's The Sands of Mars (1951) ${ }^{6}$ and Frank Herbert's Dune (1965). ${ }^{7}$ Often, the terraformed planet, usually Mars, offers a striking parable of how best to manage environmental disaster on Earth, for example, in The Greening of Mars by James Lovelock and Michael Allaby (1984) ${ }^{8}$ and in Kim Stanley Robinson’s 'Mars' trilogy, Red Mars (1992), ${ }^{9}$ Green Mars (1993) ${ }^{10}$ and Blue Mars (1996). ${ }^{11}$ Robinson’s 'Mars' novels, which won both the Hugo and Nebula awards, amongst science fiction's most prestigious accolades, 
detail hundreds of years of the colonisation and gradual transformation of the Martian biosphere to render it fit for human habitation.

In the case of science fiction narratives set on Earth rather than other planets—often known as 'future histories'12 because their other-worldliness is derived from their futuritywe find a trend towards ecological themes from the 1970s onwards. (Although future histories of significantly altered environments occur earlier than this, these tend not to deal with anthropogenic ecological change. For example, Hothouse [1962] by Brian Aldiss ${ }^{13}$ and The Drowned World [1962] by J. G. Ballard ${ }^{14}$ depict a world climatically changed through dramatic but natural causes.) It is with the heightening of environmental awareness in the last three decades of the twentieth century, around issues such as bio-chemical pollution, acid rain, ozone depletion, and the greenhouse effect, that future histories begin to be more overtly and polemically environmental, whether as utopias or dystopias (generally, that is, whether optimistic or pessimistic about the future). The first of these is Ernest Callenbach's distinctly utopian Ecotopia (1975), ${ }^{15}$ while other notable utopian examples are its less successful prequel Ecotopia Emerging (1981) ${ }^{16}$ and Ursula K. Le Guin’s Always Coming Home (1982). ${ }^{17}$ However, such hopeful depictions are out-numbered by darker visions, including Marge Piercy's Woman on the Edge of Time (1976), ${ }^{18}$ Hal Clement's Nitrogen Fix (1980), ${ }^{19}$ Trevor Hoyle’s The Last Gasp (1983), ${ }^{20}$ Brian Stableford and David Langford's The Third Millennium (1985), ${ }^{21}$ Whitley Strieber and James Kunetka’s Nature’s End (1986), ${ }^{22}$ and Robert Silverberg’s Hot Sky at Midnight (1994). ${ }^{23}$ Robinson, whose 'Mars' novels offer an analogy for environmental management on Earth, presents not just environmental change but alternative ways of mitigating it in his 'Three Californias' trilogy, The Wild Shore (1984), ${ }^{24}$ The Gold Coast (1988) ${ }^{25}$ and Pacific Edge (1990), ${ }^{26}$ which he designates as 'the after-thefall, the dystopia, and the utopia’ (52) respectively. ${ }^{27}$ 
Not unexpectedly, it is in the 1970s, too, that the history of climate change fiction begins in earnest. The first novel to engage directly with what we now call climate change is Arthur Herzog’s Heat (1977), a plausibly imagined future history dominated by global warming. ${ }^{28}$ Another milestone novel is George Turner's The Sea and the Summer (1987, published in the US as Drowning Towers), which oscillates between far and near futures beset by dramatically rising sea levels. ${ }^{29}$ Mention must be made, too, of Morgan Llywelyn’s fantasy The Elementals (1993) ${ }^{30}$ and Norman Spinrad's sci-fi thriller, Greenhouse Summer (1999), ${ }^{31}$ both of which depict rising sea levels and climate disaster.

The science fiction representations of climate change we have surveyed thus far have tended to depict climate change in the relatively straightforward terms of setting (the otherworldly novum). In this century, however, Robinson has emerged as science fiction's most important writer to deal explicitly with the problem of climate change, not simply as the premise for an other-worldly setting but as a social, cultural and political phenomenon and problem, requiring unusual methods of characterisation and plot. Following his environmentally charged 'Mars' and 'Three Californias' trilogies, Robinson’s 'Science in the Capital` trilogy, comprised of Forty Signs of Rain (2004), ${ }^{32}$ Fifty Degrees Below (2005) ${ }^{33}$ and Sixty Days and Counting (2007), ${ }^{34}$ depicts a near-future scenario in which environmental science and political will must unite in order to redress climate change disaster. A similarly innovative response is Paolo Bacigalupi’s very recent The Windup Girl (2010), winner of both Hugo and Nebula awards, a vivid picture of a climate-changed future in which energy scarcity, rising sea levels, and genetically modified diseases and food sources have transformed human experience. ${ }^{35}$

The growing 'green' concerns of the past four decades have, of course, had a discernible influence on literature beyond science fiction. Climate change, and environmental disaster more generally, have been dealt with by a range of novelists not normally identifiable 
with science fiction. However, many such novels are similar to the ecological future histories of science fiction, as they imagine a future setting in a climate-changed Earth. On this point, then, it is worth noting that the question of whether a text is designated as science fiction or not—as with any genre-depends not simply on the characteristics of that text, but on the identification of its author with the genre and the willingness of readers to read that text and its author within those generic boundaries; marketing, it must be conceded, plays an important role in such decisions. Science fiction, in particular, functions as a community of authors and readers, built on and defined by a sense of shared identity. Plenty of non-science fiction writers adopt science fiction techniques such as novums, but are not located by their readers or critics within the science fiction community.

In surveying texts beyond science fiction, a number of thriller novels have engaged with climate change as an important theme, and as a function of plot and character rather than simply setting. It would seem that the geopolitical nature of the measures currently being taken to tackle global climate change provides promising material for conspiracy scenarios, while the idea of large-scale environmental disaster becomes a useful tool with which to create narrative suspense and climax. The most important of these thrillers, in terms of its influence, is the contrarian climate change novel, State of Fear (2004) by Michael Crichton, in which environmental activists try to trigger disasters to manufacture popular support, while the novel's heroes gradually uncover the lack of evidence for anthropogenic climate change. ${ }^{36}$ Of the conspiracy-fuelled thriller narratives on the other end of the spectrum, significant examples are: Rock Brynner's The Doomsday Report (1998), which deals with an elaborate hoax perpetrated by a conscientious scientist to shock the world into acting against climate change; ${ }^{37}$ Clive Cussler's Arctic Drift (2005), in which the good guys uncover an energy tycoon's illegal dumping of carbon dioxide and bribery-led bitumen mining; ${ }^{38}$ and Matthew Glass’s Ultimatum (2009), set in a near-future when politicians are finally forced to 
enact serious carbon reduction, and US and Chinese leaders are drawn into a political game of chicken. ${ }^{39}$ James Herbert's Portent (1992) is an example of a supernatural or horror thriller of climate change, presenting it as a manifestation of a Gaia-like supernatural force responding to humans’ overextension on Earth. ${ }^{40}$ Similarly, Liz Jensen’s The Rapture (2009) employs the techniques of the thriller genre in her depiction of a world racing towards an apocalyptic global warming disaster. ${ }^{41}$

Outside the broad genre of thriller, Ben Elton is a rare example of a humour writer taking on pre-climate change environmental concerns, namely in the realm of political satire, in novels such as Stark (1989) ${ }^{42}$ and This Other Eden (1993). ${ }^{43}$ There exists, too, a surprising number of teen novels about climate change, which tend to deal with the political and social implications of climate change. Gemma Malley’s The Declaration (2007), ${ }^{44}$ Saci Lloyd’s The Carbon Diaries $2015(2008)^{45}$ and The Carbon Diaries $2017(2009)^{46}$ are stand-out examples.

Our historical survey of climate change fiction has so far dealt with what is designated 'genre fiction', that is, fiction that is clearly identifiable with a given literary form, in this case, the well-defined genre of science fiction, as well as thrillers, satirical comedy, and teen novels. However, some novelists, particularly those who are often thought of as 'literary' or serious writers, are not often read or critiqued in terms of genre. Significantly, such 'literary' fiction, which emerges in literary studies as a category distinct from genre fiction, has come late to environmental issues—a notable exception being Paul Theroux's O-zone $(1982)^{47}$ — and to the problem of climate change in particular. Moreover, many highly regarded authors have dealt with climate change by setting their novels in worlds that are obviously climatechanged by human irresponsibility but not explicitly linked to the current anthropogenic crisis. Nonetheless, for reasons we will outline below, it is 'literary' fiction, rather than genre fiction, that tends to become the focus of literary scholarship. 
Examples of 'literary' fiction that deals in less direct fashion with climate change are Maggie Gee’s The Ice People (1998) ${ }^{48}$ and The Flood (2004), ${ }^{49}$ Doris Lessing's Mara and Dann (1999) ${ }^{50}$ and its sequel The Story of General Dann and Mara's Daughter, Griot and the Snow Dog (2006), ${ }^{51}$ Margaret Atwood's Oryx and Crake (2003) ${ }^{52}$ and The Year of the Flood (2009), ${ }^{53}$ Will Self's The Book of Dave (2006), ${ }^{54}$ and Cormac McCarthy's The Road (2007). ${ }^{55}$ More direct engagements with the current crisis can be found in T. C. Boyle’s A Friend of the Earth (2000), set in 2025, when the Earth has been devastated by global warming brought on by extreme deforestation, ${ }^{56}$ and Jeanette Winterson's The Stone Gods (2008), which depicts Earth in the far future so destroyed by climate change that it is no longer able to sustain life. ${ }^{57}$ Finally, worth noting, too, are a handful of recent climate change novels by less well-known but promising 'literary' authors, amongst them, Sarah Hall's The Carhullan Army (2007), ${ }^{58}$ Sarah Moss’s Cold Earth (2009), ${ }^{59}$ and Marcel Theroux’s Far North (2009). ${ }^{60}$ The novels listed here tend to adopt future-history approaches to climate change, depicting substantially or spectacularly altered climate-changed settings, but it should be noted that they also go on to deal, in formally innovative ways, with the challenges these present to their protagonists.

More recently, Ian McEwan, with Solar (2010), has come at the question of climate change from the perspective of a morally-compromised scientist. ${ }^{61}$ This long-awaited climate change novel is a rare example (along with Elton) of mixing comedy with environmental issues. It is also distinctive in its emphasis on climate change as an ethical dilemma for the present rather than environmental disaster set in the future; as we have suggested, the majority of climate change fiction uses climate change as a setting (although it also may deal with its implications through characters and plot).

\section{LITERARY STUDIES AND CLIMATE CHANGE}


As our survey of fiction suggests, one of the first tasks for any literary scholar interested in fictional representations of climate change is to identify literary texts that will repay sustained attention. Much literary research is carried out by performing a close analysis on a single text, investigating what it might have to say and situating its ideas against wider historical, intellectual, cultural, or scientific currents, or against other writings by the same author. These single-text, and sometimes single-author, interpretations identify 'interesting' texts and authors that can form a background for broader, comparative studies. Such studies are also valued because they provide a high level of resolution about the interpretation of important works and writers.

As a result, some of the most notable scholarship on literature and climate change has taken the form of articles interpreting single texts and authors. It is worth noting that the vast majority of such research has occurred in the last decade, and therefore they have exerted almost no influence on each other. (Compared with the sciences, literary studies has a particularly long research cycle and slow reaction to disciplinary developments, due to the duration of research projects and extremely long lead times in review and publication).

In carrying out such single-text and author studies, critics tend to be interested in a very narrow band of writing: most such research is focused on the highly regarded novelists we have identified as 'literary’, who are celebrated for particular kinds of formal innovation, the 'seriousness' of their work, their interest in character and human interaction, and their engagement with 'history' and the intellectual currents of the academy. Importantly, then, such texts often move beyond questions of setting in an effort to do justice to the complexity of the issue of climate change.

Nonetheless, whilst such 'literary' texts and authors offer important examples of creative inventiveness, this emphasis on a select group of texts, or canon of authors, means that certain kinds of climate change novels are unreasonably neglected. Genre fiction is often 
perceived to be beneath scholarly attention. Some scholarship does take place in these areas—-science fiction research is easily the most robust—but this work is often understood to be separate from research into 'literary' fiction. These prejudices have been a significant hindrance to scholarship on climate change literature, because probably the vast majority and the most read of fictional engagements with climate change are genre novels. Further, as we suggest below, genre fiction offers, in its own way, evidence of how climate change evokes and provokes literary innovation.

In addition to considering specific single-author criticism—which dominates literary scholarship—it is necessary to understand the broader literary scholarly context for such criticism. Any literary study of climate change by definition engages with, or sits within, the critical category of ecocriticism, or environmental criticism. The most oft-quoted definition of ecocriticism is 'the study of the relationship between literature and the physical environment' (xix) ${ }^{62}$. However, while such a definition would mean that ecocriticism subsumes all literary criticism about climate change, it is important to understand ecocriticism as a praxis determined by a set of attitudes toward the physical environment and therefore as a somewhat more specific grouping of literary critics.

Strikingly, ecocriticism in these more specific terms has, for historical and methodological reasons, only recently engaged with the issue of climate change. We consider here the reasons for this, and the prognosis for further ecocritical engagement with climate change. In this light, we discuss too the explorations of climate change offered by other literary critical approaches, particularly those placed under the rubric of 'critical theory' and those that offer historicist readings of past environmental change. Specifically, we note discussions in critical theory of the ways in which the problem of climate change might prompt a reassessment (in a specifically 'deconstructive' mode) of some of the assumptions that underpin environmentalism, as well as historicist investigations of older literary texts and 
authors for the way in which they shed light on the current environmental situation. We posit that these developments outside ecocriticism represent a valuable contribution to our understanding of cultural responses to climate change, with the possibility of a useful crossfertilisation with ecocriticism.

Our overview of literary scholarship on climate change, therefore, is structured as follows. We survey the critical responses offered by studies of specific climate change texts and authors, offering brief descriptive notes, too, of these novels. While we discuss, in the main, ostensibly 'literary' novels and their criticism, we consider an exception to this in genre fiction, that is, the climate change novels of science-fiction writer Kim Stanley Robinson, and provide an analysis of Robinson's work in order to demonstrate the utility of engaging with genre fiction. We then discuss ecocriticism and its relationship with climate change fiction, before focusing on critical theory and eco-historicism.

\section{Single-Text and Single-Author Interpretations}

In the last decade, there has been a considerable rise in the number of self-consciously 'literary’ authors writing about climate change. This has led to a vast increase in scholarship on the subject, for their novels have received a great deal of individual attention. Most of the novels in question deploy a level of sophistication and complexity that rewards careful study. Whilst these critical engagements do not necessarily deal with climate change, further work on climate change in these novels is easier because critics can depend on previous interpretations in developing new arguments.

Atwood's Oryx and Crake has likely received the most attention as a single novel dealing with climate change. (Atwood is an extremely popular novelist, supports a critical industry, and is a fixture on undergraduate reading lists). In the world of Oryx and Crake, not just climate change, but rampant genetic modification carried out by repressive corporation- 
led regimes, have led to species extinction and deadly virus epidemics. There has been a considerable amount of scholarship about Atwood's depiction of ecological destruction, particularly the novel's disturbing vision of extreme bioengineering. Much of this scholarship mentions climate change as important to the novel's setting, but does not deal explicitly with the question of how Atwood engages with it. For example, Howells ${ }^{63}$ and Korte $^{64}$ read the novel as a 'Last Man' narrative, a genre that explores what it might mean to witness the extinction of human beings, and, in doing so, note the significance of global warming to Atwood's vision. Similarly, Glover, ${ }^{65}$ Hengen, ${ }^{66}$ and Wolter, ${ }^{67}$ in discussing the novel as a critique of instrumentalist attitudes to the environment, nod at climate change as one of the targets of this critique. This critical trend, in which Atwood's concerns about climate change are recognised but not explored at length, has continued with the appearance of Atwood's The Year of the Flood (2009), a companion novel to Oryx and Crake. For example, Bergthaller has offered a very recent commentary of both novels in terms of the concept of environmental sustainability, with an emphasis on defining and deconstructing that concept. ${ }^{68}$ In contrast, McCarthy's The Road, the story of an unnamed father and son journeying south to escape the worst effects of a catastrophic change in climate, has also received tremendous critical interest, but with notable emphasis on its status as a climate change novel. With McCarthy's novel, the focus is, once again, primarily on its climate-changed setting. Monbiot argues that the novel is 'the most important environmental book ever written', reading it as a depiction of 'what would happen if the world lost its biosphere, and the only living creatures were humans, hunting for food among the dead wood and soot', and situating it as a warning against not taking immediate and drastic steps to curtail anthropogenic climate change. ${ }^{69}$ In response, however, Grauland has argued that the novel's cataclysm cannot positively be identified with global warming, and that politics do not provide a useful way to read the novel. ${ }^{70}$ Other critical work, for example, Kunsa ${ }^{71}$ and Warde, ${ }^{72}$ has interrogated the 
novel's treatment of place, focusing on its barren, post-apocalyptic landscape without specifically discussing climate change.

Significantly, although Boyle is less well known than Atwood and McCarthy, his A Friend of the Earth has begun to attract attention as a climate change novel. Much of this research explores the novel's formal innovations and its depictions of the social and psychological aspects of combating climate change. The novel is one of several by Boyle that employ pointed satire and detailed research to deal with environmental themes. Set in 202526 when the biosphere has collapsed, it also looks back to the 1980s and 90s, where its protagonists are environmental activists in an Earth First!-like organization, struggling to save forests and wild animals. Mayer reads the novel as a rather bitter, postmodern satire of environmental activism as having failed to prevent the worst effects of climate change. ${ }^{73}$ Gleason, meanwhile, describes the novel as an 'important environmentalist novel on the dangers of global warming' (112). ${ }^{74}$ However, Zumbansen and Fromme, in placing the novel alongside climate change films such as The Day after Tomorrow (2004), criticise it for being more concerned with critiquing current socio-cultural conditions and adhering to narrative conventions than with raising 'environmental awareness'. ${ }^{75}$

Lessing and Gee have received considerably less attention for their representations of climate change. In the case of Lessing, one factor in this is that Lessing scholarship demonstrates a more selective and nostalgic approach than, say, Atwood scholarship, and therefore Mara and Dann is less analysed than the author's better-known early novels. Mara and Dann is set in the far distant future, after a new Ice Age has made Europe uninhabitable, and tells of the eponymous sister and brother as they journey through Africa as climate refugees. Becket is one of few critics to read this as specifically concerned with anthropogenic climate change; she sees it as an environmental parable of the current crisis, 'highlighting the frailty of advanced technology in the face of climate change' (141). ${ }^{76}$ 
Meanwhile, strikingly, neither of Gee’s climate novels has been critiqued as dealing explicitly with the current global warming crisis, although the threatened environments of both novels would seem to invite such treatments. The Ice People has received little critical attention, while Dillon has read The Flood as a response to the 9/11 attacks and (somewhat anachronistically) the Boxing Day tsunami of 2004, but neglects the rather obvious interpretation that the flood of the novel's title has been brought about by climate change. ${ }^{77}$

As relatively recent novels, the novels by Winterson, Self and McEwan have yet to generate a significant body of research, but it is likely, given the considerable attention devoted to the authors' other works, that they will do so in time. Ellam's recent study of Winterson's work includes a commentary on The Stone Gods, criticising the use of the lost mother as a metaphor for the physical disintegration of the planet, suggesting that 'it tends to relegate the fate of the ecological system' (224) to the emotional needs of the character. ${ }^{78}$ Self's The Book of Dave, in which a benighted future society lives on the remaining islands of a flooded Britain, worshipping the written ravings of a demented cabbie named Dave, has been discussed by Rospide ${ }^{79}$ for its innovative temporal structure, but not yet for its environmental concerns (although Clark, ${ }^{80}$ whose research we discuss below, has read Self's short story 'Waiting' in terms of a deconstructive environmental criticism). Similarly, Solar, which generated much pre-publication hype as McEwan's long-awaited climate change novel, will almost certainly be the focus of much research. Already, Garrard has offered a playful engagement with the novel, analysing it before it was published. ${ }^{81}$

As noted above, the exception to the 'literary' emphasis of single-text interpretations of climate change is Robinson's 'Science in the Capital' trilogy. Identifying himself as a writer who has been 'interested in global warming for a long time', Robinson confronts headon the problem of mitigating climate change in these recent novels. ${ }^{82}$ Critical attention has tended to focus on the novels' manipulation of science fiction conventions in its effort to 
depict the scale and complexity of climate change. For example, Luckhurst has read the trilogy as a deliberately realist rather than science-fiction account of climate change, as it offers pragmatic solutions 'within the horizon of current scientific research', ${ }^{83}$ Prettyman compares its generic experimentation to genetic hybridity, ${ }^{84}$ and Johns-Putra suggests that it represents a re-negotiation with existing conventions in utopian science fiction. ${ }^{85}$ Meanwhile, other critics have commented on the novels in terms of the efficacy and desirability of their scientific interventions: Murphy discusses the ethics of Robinson’s bioengineering solutions to climate change, ${ }^{86}$ while Yanarella and Rice have argued that these solutions rest on a relatively naive Enlightenment view of science. ${ }^{87}$

Robinson’s 'Mars' trilogy has also been discussed in terms of its environmentalist agenda, particularly its portrayal of 'eco-economics', a scientifically-informed, ethicallyminded green socialism that allows Mars to be successfully terraformed. Burling, ${ }^{88}$ Franko, ${ }^{89}$ Markley, ${ }^{90}$ Otto, ${ }^{91}$ and Swidorski, ${ }^{92}$ for example, have all explored and praised the way in which this progressively green political system is unfolded in the course of the trilogy. Buell, meanwhile, has suggested that the 'Mars' trilogy ultimately fails as a 'model for Earthly ecological reconstruction’ (278) precisely because it does not take place on Earth. ${ }^{93}$ One could argue that the 'Science in the Capital' trilogy manages just the kind of direct, rather than analogous, confrontation with climate change that Buell encourages.

Just how Robinson achieves this can be seen by critically examining the reader's experience of the 'Science in the Capital' trilogy against the expectations generated by the 'Mars' trilogy. For reasons of space, this brief reading is the only critical textual analysis that we are able to offer here, but we hope it provides a case study of how explorations of both genre fiction and 'literary’ fiction are able to deepen our understanding of the literary innovations demanded by climate change. 
Robinson's earlier trilogy, as a typical science fiction text, utilises the imaginative effect of the novum in its careful depiction of the terraforming of Mars, its significant appeal lying in the exhaustive detail with which this fictional world is represented. Indeed, Gersdorf perceptively describes this narrative technique as 'figurative terraforming' (37), a term that evokes the way that Robinson both depicts the act of world-building on Mars and also selfconsciously builds this world for his readers. ${ }^{94}$

Robinson’s more recent climate change trilogy adopts a similar approach: it portrays what the author himself has described as terraforming Earth, ${ }^{95}$ using narrative methods that could again be termed figurative terraforming. Once more, setting is described in vivid detail, with the streets of Washington, DC so faithfully reconstructed that they would be recognisable to a native of the city (indeed, recalling the way James Joyce's depiction of Dublin in Ulysses is able to be recreated by Joycean enthusiasts every Bloomsday). Speech is reported in a way that conveys immediacy: conversations are presented as almost pure dialogue without the usual interpolations of 'he said' and 'she said'. Also worth noting in relation to this mode of world-building is the sheer length of the trilogy, especially if readas Robinson intended — as a single text, a kind of triple-decker. ${ }^{96}$ Thus, detail of description is matched by scale of plot, and the world of the trilogy assumes both breadth and depth.

Yet, the trilogy's setting — a near-future Earth—is not a novum in the same way that Mars is. This poses the question of why Robinson indulges in such careful world-building when the world being built is hardly alien, hardly new. The answer lies in the intended effect of such a narrative mode on the reader. To understand this, one must understand, too, Robinson's definition of his science fiction as utopian and, further, his definition of utopianism. In interviews, Robinson has consistently pointed out that his utopian worlds, far from being presented in all their perfection, are shown in the process of being achieved. ${ }^{97,98}$ As Jameson has noted of Robinson's brand of utopian science fiction, 'utopia as a form is not 
the representation of radical alternatives; it is rather simply the imperative to imagine them' $(231){ }^{99}$

In Robinson’s 'Science in the Capital' trilogy, then, the reader does not look upon utopia as a setting, but experiences utopia in and as progress. One is made aware of characters’ psychology through dialogue and in a manner that resembles the slow process of getting to know people in the so-called real world; one walks and travels with these characters through the cityscape or landscape; and one is embedded, like them and with them, in the various milieux in which they work and live. All this occurs in order actively to invite and involve the reader.

This world in which the reader is invited to participate is no exciting science fiction novum but Earth in the midst of climate change. Nevertheless, Robinson adopts and adapts science fiction modes in order to convey some of the complexity of response that is needed to cope with climate change, a response shaped by participation and co-operation rather than individualism or heroism. This is further emphasised through the use of an ensemble cast of equally developed characters rather than a single protagonist. In the final analysis, the exhaustive world-building of the 'Science in the Capital' trilogy happens on several levels: it takes place not simply as an act of authorial imagination and readerly consumption but in order to convey the immense ideological effort exerted by the trilogy's characters in imagining and maintaining a better world in the face of extreme climate change.

\section{Ecocriticism}

The majority of research and methodological discussion about climate change literature has been under the broad grouping of ecocriticism. Ecocriticism, or environmental criticism, is a hybrid discipline, loosely comprised of researchers investigating questions to do with literature, culture, and the environment. Although a few critics had been calling themselves 
'ecocritics' for longer, the grouping began to gain momentum in the 1990s, as witnessed by the inauguration of the Association for the Study of Literature and the Environment (ASLE) in the US in 1992, and the subsequent establishment of affiliate organisations in the UK and Ireland, continental Europe, Australasia, Canada, India, and East Asia.

One of the most important influences on ecocriticism was the prior success of other sub-disciplines, including feminist and gender studies, race-based studies, and postcolonialism. All of these areas are political in their attempts to change dominant ideologies. Advocates of ecocriticism have hoped to do the same, using literary critique to show the shortcomings of our current environmental ideas, to draw attention to environmental issues, to develop new ways of thinking about the environment, and to energise environmental activism.

Another strand of ecocriticism has advocated interdisciplinary studies, exploring ties between literature and ecology, human and physical geography, biology, and evolutionary sciences. Studies in this direction—of which Meeker is an early example—-have ranged from investigations of how evolutionary ideas influence an author to full-scale attempts to theorize literature through ecological or evolutionary ideas. ${ }^{100}$ Thus far, ecocritics have been primarily focused on life sciences, and there has been very little ecocritical work connecting climatology and literature.

A third strand of ecocriticism traces ideas of nature in literature. To some extent, this strand is historical, insofar as it seeks to recover ideal formulations of nature in past texts. Throughout history, literary texts have made spiritual promises to give access to a deeper relationship between the reader and the natural world 'as it really is', and ecocritics have variously examined and endorsed these promises in their work. Many ecocritics trace their worldview to English Romantic poets such as Wordsworth and Shelley, American 
transcendentalists like Thoreau and Emerson, and subsequent writers working in the Romantic and transcendentalist traditions.

It must be emphasized that ecocriticism, then, is a very capacious grouping within which sit defined strands of researchers; certainly, its interdisciplinary and spiritual methodologies have often been at odds. In any event, ecocriticism, broadly defined, gathers a large quantity of literary research, and has been an important space in which to germinate work on climate change literature.

Nonetheless, the contours of ecocriticism as we have described them go some way to explaining why it has been relatively slow to engage with climate change. There has long been a political need to deal with the issue, but earlier research too often subsumed climate change under the vague heading of 'the environmental crisis'. Then, ecocriticism's interdisciplinary work tended to focus on life and landscape, providing few clues for how to connect climate and literature. In addition, the ecocritical emphasis on nature as it is imagined by eighteenth- and nineteenth-century writers has deflected attention away from the very contemporary discussion of anthropogenic climate change. Similarly, the anti-technological and spiritual dispositions of some ecocritics have not always encouraged the encounter of scientific data. Finally, the focus on nature, landscape, setting and place has been inimical to a development of a critical method for understanding both the complexity of climate change and the formal innovations of literature as it represents this complexity. Overcoming these difficulties has been slow, but, crucially, a number of leading ecocritics have begun to turn their attention to climate change as a problem.

The most significant step taken by ecocriticism in addressing climate change has been a reconsideration of the values at its very heart—nature and place. Morton has provocatively and controversially argued that ecocriticism's dependence on literature from the Romantic period and the concept of nature itself have been 'getting in the way of properly ecological 
forms of culture, philosophy, politics, and art' (1). ${ }^{101}$ For Morton, an overdependence on the idea of nature as an ahistorical phenomenon makes it impossible to think about climate change: not only is there no climate outside of temporal change, but also there is "no "nature" outside the problem of global warming that will come and fill us in on how to vote' (166168). These insights lead Morton to investigate very different aesthetic forms than have previously been of interest to ecocritics.

Following from this, Heise's Sense of Place and Sense of Planet (2008) has been groundbreaking for ecocriticism and will probably prove significant to future studies of climate change. ${ }^{102}$ While ecocriticism had been preoccupied with concepts of place and human attachment to particular landscapes, Heise emphasises the importance of the global alongside the local as cultural frames with which to understand environmental problems. In her brief epilogue, Heise specifically discusses climate change and flags up further directions for research. Exploring a number of fictional texts about climate change, she finds that the difficulty of understanding the problem and 'conveying a sense of the quite divergent impacts it might have on communities around the globe is a task of such magnitude that relatively few writers and filmmakers have attempted it so far, and those who have-with a few exceptions — have done so with limited success' (206). However, Heise recognizes that some fictions exhibit an innovative approach, which she identifies as a nascent 'eco-cosmopolitan environmentalism' (210), as they grapple with the issue.

Other key figures in eco-criticism have begun to engage with the question. Slovic, the founding president of ASLE, has explored how the field might approach climate change, emphasising the role of language—and especially literature—in shaping and communicating personal values and ‘communicating scientific ideas' on global warming (118). ${ }^{103}$ Slovic suggests a range of representations of climate he would hope to see critiqued, including novels like Crichton's State of Fear; Susan Gaines’s novel about the role of science in 
contemporary society, Carbon Dreams; ${ }^{104}$ and John Steinbeck’s classic novel about the 1930s Dust Bowl, The Grapes of Wrath. ${ }^{105}$ Thus, Slovic allocates to ecocriticism the tasks of critiquing political positions hostile to environmentalism; exploring the role of climate change science in society; investigating historical responses to climate change; and interpreting how anthropogenic climate change is enunciated in contemporary discourse. Emphasising the cultural as well as scientific aspects of climate change, he concludes that the current global crisis has occurred 'not because of how ecosystems function but rather because of how our ethical systems function' (130-1). Yet, Slovic offers little detail about just how ecocriticism might reconfigure its methods in order to carry out the task of analysing the cultural phenomenon of climate change.

Kerridge, founding president of ASLE in the UK, has interrogated the relationship between ecocriticism and climate change more rigorously. Like Heise, he emphasises the status of climate change as a global phenomenon, suggesting that fictional narratives of climate change must offer 'mediation between embodied sensuous perception and ... wider perspectives’ (72). ${ }^{106}$

Moreover, Garrard, ASLE’s current president in the UK, in addition to considering the impact of McEwan's Solar on ecocriticism, has explored McKibben's claim that climate change signals 'the end of nature', through a reading of Samuel Beckett. In dealing with Beckett’s plays, Garrard's argument pushes beyond ecocriticism’s previous preference for detailed, realist representations of nature. ${ }^{107}$ Overall, these studies suggest a major development in ecocriticism, that is, a shift in its focus and methodologies to accommodate a sustained investigation of climate change and literature.

Such a shift, it would seem, is gaining momentum. In several ecocritical fora in 2010, climate change was the focus of close literary criticism. A special 'Ecocriticism' issue of the journal English Studies contains several articles dealing with climate change fiction, from 
Bergthaller's comparison of Atwood's two novels and Johns-Putra's reading of Robinson's 'Science in the Capital' trilogy (both of which we have already discussed), to Gifford's analysis of biosemiotics in Jensen's The Rapture ${ }^{108}$ and De Bruyn’s placement of McCarthy’s The Road in ecocritical context. ${ }^{109}$

Also promising is the recent ecocritical collection, Local Natures, Global Responsibilities, which offers a number of different directions for researching literature and climate change and particularly encourages a rethinking of configurations of the local and the global. These include Wolter's reading of Atwood's Oryx and Crake, Zumbansen and Fromme’s exploration of Boyle's A Friend of the Earth (both of which we have previously mentioned) and Schroder's critique of The Day after Tomorrow and other Hollywood disaster movies. ${ }^{110}$ Two other chapters in the collection focus on the relationship between human choice and climate change: Garrard reads novels by Atwood and McEwan in order to argue that the interactions between genes, evolution, and culture need to be better understood in order to address the causes of climate change, ${ }^{111}$ while Taniama explores the limitations of understanding human character in terms of climate. ${ }^{112}$

In the last year, several other articles have sought to extend ecocritical approaches to climate change. Reading Turner's The Sea and the Summer, Maxwell has argued that postcolonial and environmental criticism can usefully supplement each other, tracing global capital and contemporary environmental attitudes in fiction about global warming. ${ }^{113}$ And Teeuwen has posited that J. G. Ballard’s ecological disaster fiction creates a useful humility in the face of climate change, but that a humanist undertaking to preserve ourselves and nonhumans is ultimately needed. ${ }^{114}$

Finally, this year’s ASLE conference in Bath, jointly hosted by the organisation's UK and Europe chapters, ${ }^{115}$ as well as the ASLE-sponsored 'Culture and Climate Change 
Symposium' that preceded it, ${ }^{116}$ contained extensive work directly engaging with literature and climate change, much of which is likely to be published in the next year.

\section{Critical Theory: Deconstruction and Environmentalism}

Such acknowledgement in ecocriticism of the importance of climate change as an object of study is paralleled by moves in literary critical theory more broadly. Generally speaking, critical theory refers to the study of critical methodology and epistemology in literary studies, rather than the more conventional study of literary texts—it is, as it were, the study of literary study. Drawing on thinkers like Nietzsche, Marx, Freud, Foucault, and Derrida, it incorporates the critical movements of structuralism, post-structuralism, post-modernism, and deconstruction.

Several important deconstructive engagements with climate change have appeared quite recently, presaging more work in the area. Inspired by Derrida, deconstruction seeks to reveal hidden contradictory meanings within a given text, subjecting its language to close analysis in the process. Deconstructive attitudes and methodologies can also be directed at cultural phenomena more generally, resulting in deconstructions of such apparently rigorous but deeply incoherent codes as those which govern media, fashion, and politics.

Two prominent deconstructionists have recently read climate change itself as a phenomenon that allows us to deconstruct some of the ideological assumptions that underpin modern Western lifestyles. Whilst such a deconstructive potential is not necessarily restricted to climate change (one could say the same thing of other socially revolutionary developments, such as the internet) it is significant for environmental criticism that concepts from critical theory are being applied to environmental concerns in this way.

Cohen argues, somewhat broadly, that climate change provides evidence that contemporary technological, philosophical, and economic orders 'appear to be reaching self- 
generated limits', leading to a complicated situation in which climate change is both of our culture and beyond it at the same time. ${ }^{117}$ In addition, Cohen is co-editor, with Sussman, of the forthcoming Atlas of Critical Climate Change, whose essays are intended as case studies of various cultural, scientific and political assumptions that are being fundamentally transformed in a climate-changed world. ${ }^{118}$ The 'Critical Climate Change' series at Open Humanities Press, co-edited by Cohen and Colebrook, invites investigations in a similar spirit. $^{119}$

Clark, like Cohen, argues that climate change ‘deconstructs' existing models of thought, including Baconian objectivism, market economies, the nation state, the individualistic liberal rights tradition, and 'development' as material affluence. ${ }^{120}$ More recently and perhaps more importantly, Clark has edited a special issue of The Oxford Literary Review on 'Deconstruction, Environmentalism, Climate Change', whose essays explore the resources and limitations of deconstruction in response to climate change, and offer deconstructions of various socio-political responses to climate change. Thus, Pinkus deconstructively critiques carbon management, ${ }^{121}$ and Teo subjects biodegradability and the ethics of responsibility to a comparable treatment. ${ }^{122}$ In a commentary that echoes the moves within ecocriticism that we have outlined above, Clark heralds the end of the ecocritical movement, deeming it to have been effectively deconstructed by climate change. ${ }^{123} \mathrm{~A}$ further important development of this collection is a growing consensus that resources from Science and Technology Studies may be central to environmental criticism. Ecocritics have long been aware of Latour's work, ${ }^{124}$ but Goeminne and François, ${ }^{125}$ following the work of Potter, ${ }^{126}$ argue for its indispensability in understanding climate change as a simultaneously social and natural 'thing' and not subject to traditional models of representation.

It is both intriguing and encouraging that ecocriticism and critical theory should find common ground in a growing intellectual curiosity about climate change, given the historical 
animosity between the two movements, broadly conceived. In particular, the emphasis in critical theory on culture and language, especially on language as the ground on which culture is constructed, has meant it has found little favour with ecocriticism, which, in contrast, has tended to invest in the spiritual importance of the natural world. Nonetheless, the insights offered by deconstruction into climate change as a factor in triggering a major shift in both scientific and cultural values would seem potentially useful to, and congruent with, ecocritical analyses of the way in which climate change requires a reconsideration of nature and place.

\section{Eco-historicism}

Notwithstanding the currents we have just surveyed in literary criticism and its theoretical approaches, the vast majority of literary research is historicist. Research tends to be divided into historical periods, and job descriptions tend to be organised around these periods. Historicist scholarship provides insight into the political, economic, and social context of literary works, and it also helps recover literary texts from past periods that have fallen into obscurity. This could suggest that the discipline is conservative, and it is certainly true that research into major figures like Shakespeare, Wordsworth, and Austen underpins the discipline. Yet, historicism sometimes also provides a tool for literary studies to respond to contemporary concerns, critiquing ‘old’ authors while investigating new ones for their views on gender, race, empire, class, sexuality, and so forth. Of relevance to our purposes is the appearance, in the last decade, of historicist studies of climate change and literature. Although often the boundaries between historicist and theoretical work are slippery, we employ the distinction here as a useful means of categorizing climate change criticism to date. 
Much of the historicist work to date has explored how earlier literature provides a useful lens to understand contemporary issues around global warming, with particular attention to psychological and social responses to climate change. Hiltner draws parallels between seventeenth-century London writers confronting air pollution from coal burning and the representational difficulties of confronting climate change in the present. ${ }^{127}$ Specifically, he finds that in both periods, it is easier at both rhetorical and emotional levels to blame industry than to acknowledge the public’s fuel consumption to be largely responsible for the problem, particularly given the difficulties in reducing this consumption. Meanwhile, Bartels proposes that William Morris, the nineteenth-century author, socialist, and advocate of craftbased labour, may provide a more useful model of utopia in an era of climate change than Marxian or other utopian texts. ${ }^{128}$ In News from Nowhere, Morris critiques air pollution, fossil fuel industries, environmental degradation, and capitalist production, and provides a vision of small, self-sufficient communities and clean energy in their place, which Bartels connects to social experiments in sustainable community-building in the late 1990 s. ${ }^{129}$ Gottlieb has compared the power dynamic in Herman Melville’s 1855 novella, Benito Cereno, about a slave ship uprising, to the relations between unequal partners in UN climate discussions like the Kyoto Protocol. ${ }^{130}$

Moving in the opposite direction, Taniama finds in our present moment of climate concerns the impetus to critique the climatic determinism in F. Scott Fitzgerald's writing. ${ }^{131}$ Also working in modern literature, Middleton connects a longer history of twentieth-century writing about environmental destruction with contemporary climate change fiction, arguing that novels can do 'some of the cultural work of reconciliation between antagonistic social forces’ (218) rooted in both the natural world and history. ${ }^{132}$ It seems likely that future historical work on climate change will follow these patterns, drawing examples from the past and criticizing historical ideas in light of our contemporary knowledge. 
One of the most important developments in historicist studies of climate change, and the source of the useful label we have adopted here, is the special issue of the Journal for Early Modern Cultural Studies entitled 'Eco-historicism'. In the introduction to the edition, Wood proposes the need for research that investigates and seeks to understand how climate has influenced human culture and history, made urgent by the threat of anthropogenic climate change. ${ }^{133}$ He distinguishes this approach from climatic determinism (e.g. attributing 'laziness' and inferiority to other cultures due to their climate), which he links to European imperialism and institutionalized racism, and from whose negative lessons we can now learn. Wood argues eco-historicism can study anthropogenic climate change as it began ten thousand years ago with the development of agriculture and the domestication of hoofed animals, and provides a context for understanding the contemporary climate change crisis. (Wood also acknowledges the limits of eco-historicism, noting that no historical analogies are truly apt and that mere awareness or cautionary tales are inadequate to the present climate crisis). Thus, Wood envisions an interdisciplinary project between the climate change disciplines of climatology, geology, geography and environmental science; political, economic, and cultural history; and qualitative cultural sources like 'poems, diaries, newspapers, paintings, folklore, etc.' (4). This interdisciplinarity would enable ecohistoricism to explain 'what the hard data of historical climatology meant in cultural terms, in the minds and lived experience of the people who endured or benefitted from a specific meteorological regime, and how human cultures have both adapted to and shaped environmental change’ (4).

The subsequent articles in the special issue are impressive studies of the historical relationships between climate and culture. Gidal draws on historical, scientific, and literary texts to explore Romantic models of utopianism and melancholy. ${ }^{134}$ He finds that Shelley drew connections between climate change, social harmony, and moral perfectibility, while 
Malthus and Keats used the language of melancholy to critique dreams of absolute felicity and climatic engineering, and argues that the latter provide a more useful model for current environmental concerns. Snider draws on Royal Society reports, diaries, ballads, paintings, sermons, and other documents to investigate how a series of severe winters in the seventeenth century helped to constitute the English identity in terms of climate. ${ }^{135}$ Sudan investigates the interconnections between Enlightenment science, British colonialism, and fantasies of climate control. ${ }^{136}$ The other essays interestingly explore the historical interconnections among climate, scientific ideas, and culture in a variety of periods. Markley’s work is of particular note, reading Daniel Defoe’s The Storm for its ‘complex feedback loops between landscape, climate, and human activities'. ${ }^{137}$ Elsewhere, Markley has extended his own methodological insights into climate and culture, exploring early modern travel writing's 'complex interactions between the dynamic processes of acculturation and acclimatization', and proposing to replace ‘conventional “intellectual” or “literary” history” with an 'ecocultural approach’ (530). ${ }^{138}$

Eco-historicism is possibly most helpful as a means to develop a subtler historical understanding of literature and the science of climate. In the last twenty years, literary critics have extensively investigated the relationships between literary texts and science. A growing body of criticism, much of it conducted under the aegis of associations such as the British Society for Literature and Science and the Society for Literature, Science and the Arts, ${ }^{139}$ have traced connections, spanning the seventeenth to the twentieth century, between literature and fields like astronomy, physics, plant biology, evolution, geography, geology, economics, psychology, sociology, anthropology, and medicine, specifically connecting historical ideas to historical texts. However, to date there has been less work on weather and literature, and even less explicitly dealing with ideas of climate change. Moreover, although some of this work has been interested to extend theoretical approaches from Science and Technology 
Studies to literary criticism (as we have discussed above in relation to deconstruction), more often such research has simply been empirical, focusing on how scientific ideas in specific historical moments influenced contemporaneous literary texts. Such an approach risks anachronistically adding later ideas to novels or poems that only appear to deal with them. It is hoped that future 'eco-historicist' work on climate change will begin to redress such shortcomings, encouraging a more holistic understanding of science past and present, and an engagement with climate science in particular.

\section{CONCLUSION: A NEW LITERARY AND CRITICAL CLIMATE}

In providing an overview not just of climate change as it has been represented in fiction but also of the critical discussions of and approaches to this fiction, we have outlined important new developments and indicated distinct possibilities for further work in these directions.

First, we have suggested that climate change, as a complex cultural phenomenon, has provoked a range of fictional responses. Some are concerned with constructing climatechanged novums, either directly or indirectly employing science fiction techniques. However, many novels do more than employ climate change in terms of setting; they begin to explore the relationship between climate change and humanity in psychological and social terms, exploring how climate change occurs not just as a meteorological or ecological crisis 'out there' but as something filtered through our inner and outer lives. In this way, then, climate change asks for authorial innovation, demanding plotlines and characterisations that participate in the global, networked and controversial nature of climate change.

We have then indicated that, although 'literary' novels would be best placed to provide such innovative responses, there is a case to be made for exploring and analysing genre fiction that deals with climate change. Of course, there is much more work to be done on important, 'literary' novels that engage with climate change, and it is likely that more such 
novels by well-known and new authors alike will demand critical attention. At the same time, we hope that strands of future criticism will work against existing notions of 'literary' seriousness by carefully reading genre fiction about climate change. Currently, such novels are thought to be more formulaic, because they are easily identifiable within generic categories. Yet, such genre fiction often provides examples of useful engagements with climate change, particularly because it is in such novels that divergences from the norm are more apparent. If we assume that such divergences are sometimes demanded by subject matter-here, climate change — then it is worth looking closely at these divergences. In their challenges to generic expectations, science fiction, thrillers, and other genre fiction are able to explore the complex scientific, political, and cultural aspects of climate change. For these reasons, we hope that future work on climate change and fiction will engage more closely with these types of texts. We anticipate too that, as our critical knowledge of both 'literary' and genre fiction develops, more systematic analyses of climate change fiction will become possible.

The complexity of climate change and the corresponding formal innovations of climate change fiction will, we hope, provoke more debate about the methodological practices of literary criticism, particularly in the areas of ecocriticism, critical theory, and historicism. Where fiction engages with climate change as more than mere locale or setting, ecocriticism needs to respond —and indeed is already responding —-with a re-assessment of concepts such as ‘nature and 'place' and an imaginative reach toward global and provisional ways of construing the environment. With regard to critical theory, scholars have found that Derridean deconstruction is a useful tool to understand some of the social and literary implications of climate change, but also that past strategies of deconstruction are limited in their ability to address the problem. Future research will need to address the extent to which Marxian, psychoanalytic, feminist, Deleuzian, and Foucauldian approaches can usefully 
engage with the subject. Finally, eco-historicism offers historicist investigations into past literary constructions that both enlighten and are enlightened by the current climate change crisis. We would urge a fruitful dialogue between eco-historicist and ecocritical understandings of climate change in literature, to use the historical to shed light on the contemporary, and vice versa.

In short, the peculiar composite that is climate change as a meteorological, ecological, and cultural phenomenon demands, in its turn, a new literary and critical climate. We have attempted to offer here a survey not just of how those demands have come to be, but of how they are being met and how they might continue to be addressed.

\section{Acknowledgements}

This article is based on research that was part-funded by the European Social Fund (agreement number 09099NCO5).

\footnotetext{
${ }^{1}$ Macfarlane, R. The burning question. The Guardian (September 24, 2005). <www.guardian.co.uk/books/2005/sep/24/featuresreviews.guardianreview29> Accessed 3 November 2010.

${ }^{2}$ The Epic of Gilgamesh, ed. A George. London: Penguin; 2000.

${ }^{3}$ The Bible, ed. R Carroll and S Prickett. Oxford: Oxford University Press; 1997.

${ }^{4}$ Suvin, D. Metamorphoses of Science Fiction: On the Poetics and History of a Literary Genre. New Haven: Yale University Press; 1979.

${ }^{5}$ Stableford, B. Science fiction and ecology. In A Companion to Science Fiction, ed. D Seed. Malden, MA.: Blackwell; 2005. 127-141.

${ }^{6}$ Clarke, A C. The Sands of Mars. 1951. New York: Spectra; 1991.

${ }^{7}$ Herbert, F. Dune. 1965. London: Hodder, 1982.

${ }^{8}$ Lovelock, J and Allaby, M. The Greening of Mars. New York: Warner; 1985.

${ }^{9}$ Robinson, K S. Red Mars. New York: Bantam; 1992.

${ }^{10}$ Robinson, K S. Green Mars. New York: Bantam; 1993.

${ }^{11}$ Robinson, K S. Blue Mars. New York: Bantam; 1996.

${ }^{12}$ Stableford, B. Science fiction and ecology. In A Companion to Science Fiction, ed. D Seed. Malden, MA.: Blackwell; 2005. 127-141.

${ }^{13}$ Aldiss, B. Hothouse. 1962. London: Penguin; 2008.

${ }^{14}$ Ballard, J G. The Drowned World. 1962. London: Harper Perennial; 2008.

${ }^{15}$ Callenbach, E. Ecotopia. 1975. New York: Bantam; 1990.

${ }^{16}$ Callenbach, E. Ecotopia Emerging. New York: Bantam; 1981.

${ }^{17}$ Le Guin, U K. Always Coming Home. 1982. Berkeley: University of California Press; 2001.

${ }^{18}$ Piercy, M. Woman on the Edge of Time. New York: Knopf; 1976.

${ }^{19}$ Clement, H. Nitrogen Fix. New York: Ace; 1980.

${ }^{20}$ Hoyle, T. The Last Gasp. 1983. London: Grafton; 1990.
} 
${ }^{21}$ Stableford, B and Langford D. The Third Millennium. 1985. London: Paladin; 1988.

${ }^{22}$ Strieber, W and Kunetka J. Nature's End. New York: Warner; 1986.

${ }^{23}$ Silverberg, R. Hot Sky at Midnight. New York: Bantam, 1994.

${ }^{24}$ Robinson, K S. Wild Shore. 1984. New York: St Martin's; 1995

${ }^{25}$ Robinson, K S. The Gold Coast. 1988. New York: St Martin's; 2006.

${ }^{26}$ Robinson, K S. Pacific Edge. 1990. New York: St Martin's; 1995.

${ }^{27}$ Foote, B. A conversation with Kim Stanley Robinson. Science Fiction Studies 21.1 (1994): 51-60.

${ }^{28}$ Herzog, A. Heat. New York: Simon and Schuster; 1976.

${ }^{29}$ Turner, G. The Sea and the Summer. London: Faber; 1987.

${ }^{30}$ Llywelyn, M. The Elementals. New York: Tor, 1993.

${ }^{31}$ Spinrad, N. Greenhouse Summer. New York: Tor, 1999.

${ }^{32}$ Robinson, K S. Forty Signs of Rain. 2004. London: HarperCollins; 2005.

${ }^{33}$ Robinson, K S. Fifty Degrees Below. 2005. London: HarperCollins; 2006.

${ }^{34}$ Robinson, K S. Sixty Days and Counting. London: HarperCollins; 2007.

${ }^{35}$ Bacigalupi, P. The Windup Girl. San Francisco: Night Shade Books, 2010.

${ }^{36}$ Crichton, M. State of Fear. 2004. London: Harper Collins; 2005.

${ }^{37}$ Brynner, R. The Doomsday Report: A Novel. New York: William Morrow; 1998.

${ }^{38}$ Cussler, C. Arctic Drift. New York: Putnam; 2005.

${ }^{39}$ Glass, M. Ultimatum. New York: Atlantic; 2009.

${ }^{40}$ Herbert, J. 1992. Portent. London: Pan; 2007.

${ }^{41}$ Jensen, L. The Rapture. London: Bloomsbury; 2009.

${ }^{42}$ Elton, B. Stark. 1989. London: Black Swan; 2006.

${ }^{43}$ Elton, B. This Other Eden. 1993. London: Black Swan; 2003.

${ }^{44}$ Malley, G. The Declaration. Bloomsbury, 2007.

${ }^{45}$ Lloyd, S. The Carbon Diaries, 2015. Hodder Children's Books, 2008.

${ }^{46}$ Lloyd, S. The Carbon Diaries, 2017. Hodder Children’s Books, 2009.

${ }^{47}$ Theroux, P. O-zone. 1982. London: Penguin; 1998.

${ }^{48}$ Gee, M. The Ice People. 1998. London: Telegram; 2008.

${ }^{49}$ Gee, M. The Flood. 2004. London: Saqi; 2005.

${ }^{50}$ Lessing, D. Mara and Dann. London: Flamingo; 1999.

${ }^{51}$ Lessing, D. The Story of General Dann and Mara's Daughter, Griot and the Snow Dog. 2006. London:

Harper Perennial; 2007.

${ }^{52}$ Atwood, M. Oryx and Crake. 2003. London: Virago; 2004.

${ }^{53}$ Atwood, M. The Year of the Flood. 2009. London: Virago; 2010.

${ }^{54}$ Self, W. The Book of Dave: A Revelation of the Recent Past and Distant Future. 2006. London: Penguin; 2007.

${ }^{55}$ McCarthy, C. The Road. 2006. London: Picador, 2007.

${ }^{56}$ Boyle, T C. A Friend of the Earth. 2000. London: Bloomsbury; 2001.

${ }^{57}$ Winterson, J. The Stone Gods. London: Penguin; 2008.

${ }^{58}$ Hall, S. The Carhullan Army. London: Faber; 2007.

${ }^{59}$ Moss, S. Cold Earth. London: Granta; 2009.

${ }^{60}$ Theroux, M. Far North. London: Faber; 2009.

${ }^{61}$ McEwan, I. Solar. London: Jonathan Cape; 2010.

${ }^{62}$ Glotfelty, C. 'Introduction: Literary studies in an age of environmental crisis'. In The Ecocriticism Reader: Landmarks in Literary Ecology, ed C Glotfelty and H Fromm. Athens: University of Georgia Press; 1997. xvxviii.

${ }^{63}$ Howells, C A. 'Margaret Atwood's dystopian visions: The Handmaid's Tale and Oryx and Crake'. The Cambridge Companion to Margaret Atwood. Ed C A Howells. Cambridge: Cambridge University Press; 2006. $161-175$

${ }^{64}$ Korte, B. Fundamentalism and the end: A reading of Margaret Atwood's Oryx and Crake in the context of Last Man fiction. In Literary Encounters of Fundamentalism: A Case Book. Ed. K Stierstorfer and A KernStähler. Heidelberg: Universitätsverlag Winter; 2008. 151-163.

${ }^{65}$ Glover, J. Human/Nature: Ecological philosophy in Margaret Atwood's Oryx and Crake. English Studies in Africa 52:2 (2009): 50-62.

${ }^{66}$ Hengen, S. Margaret Atwood and environmentalism. The Cambridge Companion to Margaret Atwood. Ed C A Howells. Cambridge: Cambridge University Press; 2006. 72-85.

${ }^{67}$ Wolter, I-C. Science as deconstruction of natural identity: Arthur Conan Doyle's "When the World Screamed" and Margaret Atwood's Oryx and Crak'. In Local Natures, Global Responsibilities: Ecocritical Perspectives on 
the New English Literatures. Ed. L Volkmann, N Grimm, I Detmers, and K Thomson. Amsterdam: Rodopi; 2010. 257-271.

${ }^{68}$ Bergthaller, H. Housebreaking the human animal: Humanism and the problem of sustainability in Margaret

Atwood's Oryx and Crake and The Year of the Flood. English Studies 91.7 (2010): 728-43.

${ }^{69}$ Monbiot, G. Civilisation ends with a shutdown of human concern: Are we there already?. The Guardian (30 October 2007) <www.guardian.co.uk/commentisfree/2007/oct/30/comment.books> Accessed 21 October 2010.

${ }^{70}$ Graulund, R. Fulcrums and borderlands: A desert reading of Cormac McCarthy's The Road. Orbis Litterarum 65:1 (2010) 57-78.

${ }^{71}$ Kunsa, A. 'Maps of the world in its becoming': Post-apocalyptic naming in Cormac McCarthy's The Road. Journal of Modern Literature 33:1 (2009): 57-74.

${ }^{72}$ Warde, A. 'Justified in the world': Spatial values and sensuous geographies in Cormac McCarthy's The Road. In Writing America into the Twenty-First Century: Essays on the American Novel. Ed. E Boyle and A-M Evans. Newcastle: Cambridge Scholars Publishing; 2010. 124-137.

${ }^{73}$ Mayer, S. American environmentalism and encounters with the abject: T. Coraghessan Boyle's A Friend of the Earth. In The Abject of Desire: The Aestheticization of the Unaesthetic in Contemporary Literature and Culture. Ed. K Kutzbach and M Mueller. Amsterdam: Rodopi; 2007. 221-234.

${ }^{74}$ Gleason, P. Understanding T. C. Boyle. Columbia, SC: University of South Carolina Press; 2009.

${ }^{75}$ Zumbansen, $\mathrm{N}$ and M Fromme. Ecocatastrophes in recent American (non-)fictional texts and films. In Local Natures, Global Responsibilities: Ecocritical Perspectives on the New English Literatures. Ed. L Volkmann, N Grimm, I Detmers, and K Thomson. Amsterdam: Rodopi; 2010. 274-287.

${ }^{76}$ Becket, F. Environmental fables? The eco-politics of Doris Lessing's 'Ifrik' novels. Doris Lessing: Border Crossings. Ed. A. Ridout and S. Watkins. London: Continuum; 2009. 129-142.

${ }^{77}$ Dillon, S. Imagining apocalypse: Maggie Gee’s The Flood. Contemporary Literature 48:3 (2007): 374-397.

${ }^{78}$ Ellam, J. Love in Jeanette Winterson's Novels. Amsterdam: Rodopi; 2010.

${ }^{79}$ Rospide, M. 'Dave felt the future seething, the present boiling, the past churning': Quelques cas de résurgence dans The Book of Dave: A Revelation of the Recent Past and the Distant Future, de Will Self. Etudes Britanniques Contemporaines 36 (2009): 77-88.

${ }^{80}$ Clark, T. Towards a deconstructive environmental criticism. Oxford Literary Review 30.1: (2008): 45-68.

${ }^{81}$ Garrard, G. Ian McEwan's next novel and the future of ecocriticism. Contemporary Literature 50.4 (2009): 695-720.

${ }^{82}$ Gunn, M. Interview with Kim Stanley Robinson. Tech Nation: IT Conversations. 10 January 2006.

$<$ http://itc.conversationsnetwork.org/shows/detail935.html> Accessed 30 May 2010.

${ }^{83}$ Luckhurst, R. The politics of the network: The Science in the Capital trilogy. In Kim Stanley Robinson Maps the Unimaginable: Critical Essays. Ed. W J Burling. Jefferson, N.C.: McFarland, 2009. 170-180.

${ }^{84}$ Prettyman, G. Genes, genres, and utopia in the Science in the Capital trilogy. In Kim Stanley Robinson Maps the Unimaginable: Critical Essays. Ed. W J Burling. Jefferson, N.C.: McFarland, 2009. 181-203.

85 Johns-Putra, A. Ecocriticism, genre and climate change: Reading the Utopian vision of Kim Stanley Robinson's Science in the Capital trilogy. English Studies 91.7 (2010): 744-60.

${ }^{86}$ Murphy, P D. Engineering planets, engineering ourselves: The ethics of terraforming and areoforming in an age of climate change. Journal of Ecocriticism 1.1 (2009): 54-59.

${ }^{87}$ Yanarella, E J and Rice, C. Global warming and the specter of geoengineering: Ecological apocalypse, Modernist hubris, and scientific-technological salvation in Kim Stanley Robinson's global warming trilogy. In Engineering Earth: The Impacts of Megaengineering Projects. Ed. S D Brunn. London: Springer; 2011.

${ }^{88}$ Burling, W J The theoretical foundation of Utopian radical democracy in Blue Mars. Utopian Studies 16 (2005): 75-96.

${ }^{89}$ Franko, C. The density of Utopian destiny in Red Mars. Extrapolation 38 (1997): 57-65.

${ }^{90}$ Markley, R. Dying Planet: Mars in Science and the Imagination. Durham, NC.: Duke University Press; 2005.

${ }^{91}$ Otto, E. The Mars trilogy and the Leopoldian land ethic. Utopian Studies 14.2 (2003): 118-35.

${ }^{92}$ Swidorski, C. Kim Stanley Robinson's Martian vision. In The Utopian Fantastic: Selected Essays from the Twentieth International Conference on the Fantastic in the Arts. Ed. M Bartter. Westport, CT: Praeger; 2004.

${ }^{93}$ Buell, F. From Apocalypse to Way of Life: Environmental Crisis in the American Century. New

York: Routledge; 2003.

${ }^{94}$ Gersdorf, C. 'A sort of America': Ecology and history in Kim Stanley Robinson's Mars trilogy. Tamkang Review 37.1 (2006): 29-42.

95 Robinson, K S. Imagining Abrupt Climate Change: Terraforming Earth. Seattle: Amazon Shorts; 2005.

${ }^{96}$ Robinson, K S. Imagining Abrupt Climate Change: Terraforming Earth. Seattle: Amazon Shorts; 2005.

${ }^{97}$ Foote, B. A conversation with Kim Stanley Robinson. Science Fiction Studies 21.1 (1994): 51-60; 
${ }^{98}$ Szeman, I and M Whiteman. Future politics: An interview with Kim Stanley Robinson. Science Fiction Studies 31.2 (2004): 188-99.

${ }^{99}$ Jameson, F. ‘If I find one good city, I will spare the man’: Realism and Utopia in the Mars trilogy. In

Learning from Other Worlds: Estrangement, Cognition and the Politics of Science Fiction and Utopia. Ed. P Parrinder. Liverpool: Liverpool University Press; 2000. 208-33.

${ }^{100}$ Meeker, J. The Comedy of Survival: Literary Ecology and a Play Ethic. Tuscon: University of Arizona Press; 1997. The methods for this interdisciplinarity have been contentious, particularly as attempts to locate criticism in science have been accused of 'scientism', borrowing the prestige of science without being science itself.

${ }^{101}$ Morton, T. Ecology without Nature. Cambridge, MA: Harvard University Press; 2007.

${ }^{102}$ Heise, U K. Sense of Place and Sense of Planet: The Environmental Imagination of the Global. New York:

Oxford University Press; 2008.

103 Slovic, S. The story of climate change: Science, narrative, and social action. Going Away to Think. Reno:

University of Nevada Press; 2008. 117-133.

${ }^{104}$ Gaines, S. Carbon Dreams. Berkeley: Creative Arts; 2001.

105 Steinbeck, J. 1939. The Grapes of Wrath. New York: Chelsea House; 1988.

${ }^{106}$ Kerridge, R. Environmental fiction and narrative openness. In Process: Landscape and Text. Ed. C Brace and A Johns-Putra. Amsterdam: Rodopi, 2010. 65-85.

${ }^{107}$ Garrard, G. Endgame: Beckett's ecological thought. Manuscript under consideration by Samuel Beckett Today/Aujourd'hui.

${ }^{108}$ Gifford, T. Biosemiology and globalism in The Rapture by Liz Jensen. English Studies 91.7 (2010): 713-27.

${ }^{109}$ De Bruyn, B. Borrowed time, borrowed world, and borrowed eyes: Care, ruin and vision in Cormac

McCarthy's The Road and Harrison's Ecocriticism. English Studies 91.7 (2010): 776-89.

${ }^{110}$ Schroder, N. Framing disaster: Images of nature, media, and representational strategies in Hollywood disaster movies. In Local Natures, Global Responsibilities: Ecocritical Perspectives on the New English Literatures Ed. L Volkmann, N Grimm, I Detmers, and K Thomson. Amsterdam: Rodopi; 2010. 289-306.

${ }^{111}$ Garrard, G. Reading as an animal: Ecocriticism and Darwinism in Margaret Atwood and Ian McEwan. In Local Natures, Global Responsibilities: Ecocritical Perspectives on the New English Literatures Ed. L Volkmann, N Grimm, I Detmers, and K Thomson. Amsterdam: Rodopi; 2010. 223-242.

112 Taniama, S. F. Scott Fitzgerald’s 'The Ice Palace': Climate, culture, and stereotypes. In Local Natures, Global Responsibilities: Ecocritical Perspectives on the New English Literatures. Ed. L Volkmann, N Grimm, I Detmers, and K Thomson. Amsterdam: Rodopi; 2010. 307-320.

${ }^{113}$ Maxwell, A. Postcolonial criticism, ecocriticism and climate change: A tale of Melbourne under water in 2035. Journal of Postcolonial Writing 45.1 (2009): 15-26.

${ }^{114}$ Teeuwen, Rudolphus. Ecocriticism, humanism, eschatological jouissance: J. G. Ballard and the ends of the world. Tamkang Review 39.2 (2009): 39-57.

115 'Environmental Change - Cultural Change'. University of Bath. 1-4 September 2010.

116 'Culture and Climate Change’. Bath Spa University. 31 July 2010.

${ }^{117}$ Cohen, T. Climate change in the aesthetic state (a memory (dis)order). Parallax 10:3 (2004): 83-98.

${ }^{118}$ Cohen, T and Sussman, H. eds. Atlas of Critical Climate Change. New York: Fordham University Press; 2010. <www.criticalclimatechange.com/atlas.html> Accessed 4 November 2010.

${ }^{119}$ Cohen, T. and Colebrook, C. 'Critical Climate Change'. <www.openhumanitiespress.org/critical-climatechange.html> Accessed 4 November 2010.

${ }^{120}$ Clark, T. Towards a deconstructive environmental criticism. Oxford Literary Review 30.1: (2008): 45-68.

${ }^{121}$ Pinkus, K. Carbon management: A gift of time?. Oxford Literary Review 32.1 (2010): 51-70.

${ }^{122}$ Teo, T-Y. Responsibility, biodegradability. Oxford Literary Review 32.1 (2010): 91-108.

${ }^{123}$ Clark, T. Some climate change ironies: Deconstruction, environmental politics, and the closure of ecocriticism. Oxford Literary Review 32:1 (2010).

${ }^{124}$ Latour, B. We Have Never Been Modern. Cambridge, MA: Harvard University Press; 1993.

${ }^{125}$ Goeminne, G and François, K. The thing called environment: What it is and how to be concerned with it. Oxford Literary Review 32.1 (2010): 109-130.

${ }^{126}$ Potter, E. Climate change and the problem of representation. Australian Humanities Review 46:1 (2009). $<$ http://www.australianhumanitiesreview.org/archive/Issue-May-2009/potter.htm> Accessed 4 November 2010.

${ }^{127}$ Hiltner, K. Renaissance literature and our contemporary attitude toward global warming. Interdisciplinary Studies in Literature and Environment 16.3 (2009): 429-441.

${ }^{128}$ Bartels, D. The road to nowhere: Morris, utopia, and global climate change. Journal of the William Morris Society 12:3 (1997): 39-47.

${ }^{129}$ Morris, W. News from Nowhere. 1890. London: Penguin; 2004. 
${ }^{130}$ Gottlieb, J P. Power politics and international public law: Lessons from Benito Cereno. ARIEL: A Review of International English Literature 35.1-2 (2004): 189-214.

${ }^{131}$ Taniama, S. F. Scott Fitzgerald's 'The Ice Palace’: Climate, culture, and stereotypes. In Local Natures, Global Responsibilities: Ecocritical Perspectives on the New English Literatures Ed. L Volkmann, N Grimm, I Detmers, and K Thomson. Amsterdam: Rodopi; 2010. 307-320.

${ }^{132}$ Middleton, P. How novels can contribute to our understanding of climate change. History at the End of the World?: History, Climate Change and the Possibility of Closure. Ed. M Levene, R Johnson, and P Roberts. Penrith: Humanities E-books, 2010. 218-233.

${ }^{133}$ Wood, G D. Eco-historicism. Journal for Early Modern Cultural Studies 8:2 (2008): 1-7.

${ }^{134}$ Gidal, E. 'O happy Earth! Reality of Heaven!': Melancholy and utopia in Romantic climatology. Journal for Early Modern Cultural Studies 8:2 (2008): 74-101.

${ }^{135}$ Snider, A. 'Hard frost, 1684'. Journal for Early Modern Cultural Studies 8.2: (2008) 8-32.

${ }^{136}$ Sudan, R. Climate control and the production of Anglicized weather in early modern India. Journal for Early Modern Cultural Studies 8.2 (2008): 56-73.

${ }^{137}$ Markley, R. 'Casualties and disasters': Defoe and the interpretation of climatic instability. Journal for Early Modern Cultural Studies 8.2 (2008), 102-124.

${ }^{138}$ Markley, R. Monsoon cultures: Climate and acculturation in Alexander Hamilton's A New Account of the East Indies. New Literary History 38 (2007): 527-550.

${ }^{139}$ British Society for Literature and Science $<$ www.bsls.ac.uk $>$ and Society for Literature, Science and the Arts $<$ www.litsciarts.org $>$. Accessed 11 November 2010. 